measurements of carbohydrate absorption have been made by a simultaneous determination of glycemia in the portal and the peripheral blood. Post prandial peripheral glycaemia is very high in the pig, a fact which brings into question the role of the liver in this species, but constitutes, above all, an important source of error in the determination of absorption, if only portal glycaemia is measured. Two methods of measurement have been employed, the determination of true glycaemia (glucose determination by means of glucose oxidase, Huguert and NIXON 1957), and the determination of total reducing substances using ferricyanide.

Depending on the nature of the carbohydrate, several types of carbohydrate absorption curves may be distinguished from the first results : glucose and sucrose are absorbed rapidly, while, in comparison, starch is absorbed more slowly, after a preliminary hydrolysis. Intestinal absorption may thus be characterized by its length after the start of a meal containing $400 \mathrm{~g}$ of carbohydrate, and the range in variation of glycaemia can be noted. In the case of glucose and sucrose, absorption lasts for about 4 hours, the time necessary to regain fasting glycaemia.

Absorption is much longer after a meal based on starch, and takes, in general, more than 6 hours. This time also varies with the type of starch : maize starch is more rapidly digested than manioc starch. Raw potato starch does not appear to result in a very high absorption of carbohydrates, and it would be of interest to know the manner in which it is digested in the pig. Similarly, lactose is absorbed very slowly, and only produces a very slight increase in portal glycaemia.

In addition, technological treatments (swelling, dextrinization, solubilization of starch) bring about in increase in the rate of digestion and absorption of glucose into the portal vein. In this way, gelatinized starch is digested quicker than the raw maize starch, and the dextrins are digested and absorbed more rapidly with increased solubility.

The main results obtained at the moment only allow a qualitative description of carbohydrate absorption to be given, but we hope soon to be able to formulate a quantitative description.

\title{
ÉTUDE DU TRANSPORT DES ACIDES GRAS PAR LA VOIE LYMPHATIQUE CHEZ LE PORC
}

\author{
Lucie FRÉMONT \\ Station de Recherches de Nutrition, \\ Centre national de Recherches zootechniques, I. N.R.A. \\ 78 - Jouy-en-Josas
}

Les lipides alimentaires, après avoir été absorbés par la paroi intestinale, sont collectés par le système lymphatique qui les déverse dans le sang.

L'analyse des lipides de la lymphe intestinale permet donc de connaître le sort des lipides exogènes au cours de la digestion et de l'absorption.

Des graisses naturelles ( $98 \mathrm{p}$. Ioo de triglycérides) ont été administrées à des porcs munis de fistules lymphatiques. Moins de Io $\mathrm{mn}$ après avoir été ingérés, les lipides apparaissent dans la lymphe, leur concentration augmente pour atteindre un maximum 4 à $8 \mathrm{~h}$ après l'ingestion.

Pendant cette période, les proportions des acides gras sont du même ordre dans l'ingéré et dans la lymphe. Cependant, si l'ingéré renferme un taux élevé d'acide stéarique, la proportion de cet acide gras est plus faible dans la lymphe que dans l'ingéré. Il a été montré par ailleurs que l'utilisation digestive de cet acide gras est médiocre. 
Dans la fraction phospholipides, la composition en acides gras est très peu influencée par l'ingéré ; cette classe de lipides est donc essentiellement d'origine endogène.

L'influence de la composition des lipides ingérés sur ceux de la lymphe se manifeste surtout dans les triglycérides qui représentent $80 \mathrm{p}$. Ioo des lipides totaux.

Pour connaître les transtormations subies par l'ingéré au cours de la digestion et de l'absorption, il est nécessaire de déterminer les positions des acides gras sur les molécules de triglycérides ingérés et celles des triglycérides de la lymphe. Ces recherches font l'objet de notre travail actuel.

\section{SUMMARY}

\section{A STUDY OF THE TRANSPORT OF FATTY ACIDS BY THE I,YMPHATIC SYSTEM IN THE PIG}

After the dietary lipids have been absorbed by the intestinal wall, they are collected by the lymphatic system, and then released into the blood.

Thus, the analysis of the lipids in the intestinal lymph allows the progress of exogenous lipids to be followed during digestion and absorption.

Natural fats ( $98 \mathrm{p}$. Ioo triglycerides) were administered to pigs fitted with lymphatic fistulae. The lipids appear in the lymph less than Io $\mathrm{mn}$ after having been ingested - their concentration increases and attains a maximum 4 to $8 \mathrm{~h}$ after ingestion.

The proportions of fatty acids are the same in the ingested food and the lymph during this period. However, if the food ingested contains a high amount of stearic acid, the proportion of this fatty acid is lower in the lymph than in the ingested material. It has been shown elsewhere that there is only slight digestive utilization of this fatty acid.

The composition of fatty acids in the phospholipid fraction is very little influenced by the food ingested - this category of lipids is therefore mainly of endogenous origin.

The influence of the composition of the lipids ingested on those in the lymph is particularly marked in the case of the triglycerides, which form $80 \mathrm{p}$. Ioo of the total lipids.

It is necessary to determine the position of the fatty acids on the triglyceride molecules ingested and those of the triglycerides in the lymph in order to understand the transformations undergone by the feed during digestion and absorption. This is the subject of the work that is being carried out at the moment. 271-289.

* Fremont L., Flanzy J., François A.-C., 197o. Ann. Biol. anim. Bioch. Biophys., 10, 